\title{
Improving family planning service towards sound demography and welfare policy: Lesson from decentralization reform failure in Indonesia
}

\author{
Tria Abrianty \\ Family Planning Board of Empat Lawang Regency, \\ Faculty of Public Administration \\ University of Brawijaya \\ Malang, Indonesia
}

\author{
Sujarwoto Sujarwoto \\ Faculty of Public Administration \\ University of Brawijaya \\ Malang, Indonesia
}

\begin{abstract}
Improving family planning services is vital for achieving sound demography and welfare policy. In the period 1970s-1990s Indonesia had achieved a success for controlling fertility growth and improving family welfare through centralistic family planning program. Yet, the country under decentralization reform failed to continue such success. Using mixed method, this research examines why decentralization reform in the country failed to control fertility rate and to improve family welfare and seeks what strategies to enhance sound demography and welfare policy under decentralization reform. Results of multilevel logit regression shows null association of decentralization measures on fertility rate in Indonesia. From the qualitative study in Empat Lawang Regency, decentralization reform failure is a result from many issues. First, the local government is lacking in local fiscal capacity. Second, limited number of $P L K B$ both in quantity and quality. Third, the elected regent holds most power in the region, therefore, the accomplishment of family planning programs in Empat Lawang is greatly depend on the Regent political will. From this result, some strategies can be proposed to enhance sound demography and welfare policy. First, the central government needs to take a lead in reformulation of family planning management in district level; second, major recruitment of $P L K B$ particularly for village level; third, consistent courses of re-introducing the significance of family planning to overall development goals to develop the political will of local leader in district level; and fourth, this study highlights that family planning policy could not be pursued successfully without promoting socio-economic conditions such as female literacy, the general quality of life, reproductive health and family welfare.
\end{abstract}

Keywords - family planning service; sound demography policy; welfare policy; decentralization reform.

\section{INTRODUCTION}

Improving family planning services is vital for achieving sound demography and welfare policy. Although economic development may promote a motivation to have fewer children, family planning programs are the mechanisms that enable women and men to actualize their decisions. In addition, the family planning programs helped pave the way for many subsequent health, social, and economic programs. They helped establish the feasibility to execute large-scale interventions aimed at such objectives as improving maternal and child health, eradicating disease, improving nutrition, enhancing educational opportunities, and undertaking village economic development. Of course, many health efforts were launched alongside and many kinds of programs were motivated by other sources, but the family planning efforts around the world contributed to the development of a mindset that massive, worthwhile efforts were feasible and desirable. Family planning and reproductive health services are important investments for youth, whose current opportunities (or lack thereof) will shape their countries' and regions' political, economic, and social futures. Without access to family planning and reproductive health, adolescents and young women who become pregnant are more likely to drop out of school, to not enter the labor force, and to have larger families; they and their children will then face greater challenges in remaining healthy.

Indonesia national family planning program has been recognized as one of the world's greatest demographic success stories of the 20th century [1]. In a period of 30 years from late 1960 s to 1990 s, contraceptive prevalence increased from under 5 percent to over 50 percent and the Total Fertility Rate (TFR) was cut in half, from 6 children to 3 children per woman. However, the fertility decline experienced until 1990s has not continued in the present century, fertility in 2012 was barely different from its level in 2002. According to Indonesia Demographic and Health Survey in 2002/2003 the TFR was 2.56 while in 2007 and 2012 the number had been stuck in 2.59 [2], thus bring forward the statement that Indonesia's TFR has been stalling for over one decade.

The success story of Indonesia's demographic development and fertility decline began after Suharto became president in 1967. At that time, the government started to acknowledge that the country's population problem could not be separated from its development problems [3]. The New Order's regime under Suharto administration had a very strong commitment to economic and political stability, upon which all population policy and program efforts have relied. One of effort in his population policy was the establishment of Badan Koordinasi Keluarga Berencana Nasional (BKKBN) by presidential 
decree in 1970. The head of the organization is appointed by the president and report directly to him, ensuring the effective execution of its policy and program. The BKKBN was given the mandate to coordinate all family planning activities performed by both the government and nongovernmental organizations. This strong central agency, other than supported by the president and the government itself, also received strategic, financial and technical support from international donor community. The centralistic character given by Suharto enabling BKKBN to organize vertical programs from the central level to the village, with lines of control and structures for actions implementation. The combination of strong commitment by the leader of the country and the central command of policy execution by BKKBN led the Indonesia's family planning program to become one of the world's greatest demographic success stories of the 20th century.

However, the success story discontinued after the government passed decentralization legislation in 1999. BKKBN was granted a waiver and so did not decentralize until January 2004. The most prominent change to BKKBN was the loss of central control over the program and policy. With decentralization, the BKKBN district offices were moved in most cases, where in some districts the responsibility for family planning came under the office of Health, or Population, or Civil Registration, or Women's Empowerment or some combination of these [1]. The lack of commitment by the head of local government also marked the change. Although the family planning program is still one of obligatory functions (urusan wajib) at districts levels, the priority is set below other programs such as health and education, as it is allocated a very small share of the Anggaran Pendapatan Belanja Daerah, only between 0.04 and 0.2 per cent. The past success of family planning program lay mostly in the work of Petugas Lapangan Keluarga Berencana-PLKB (family planning fieldworkers) who's the main task is to encourage the couples to adopt small family size values and to use contraception. After decentralization, the PLKB belongs to the Kabupaten/Kota and the numbers declined significantly, thus the promotion of family planning is rather neglected at the local level, with great variation between districts [4].

Based on the foregoing discussion, this research aims to examine why decentralization reform in Indonesia failed to control fertility rate and to improve family welfare and seeks what strategies to enhance sound demography and welfare policy under decentralization reform. In the next section, we discuss method used to answer the research question.

\section{METHOD}

This study uses mixed method analysis to address research questions. First, in order to examine whether decentralization relates to fertility, multilevel logit regression is applied. The individual data used in the analysis are taken from the National Socio-economic Survey (Susenas) 2012. Conducted by the government's Central Bureau of Statistics, it has been fielded yearly since 1993 and is representative at the district level. The annual sample size is about 250,000 households, in all districts in the country. This study used total 286,113 households sample and 291,636 individuals' sample. Individual samples selected were women in reproductive age (15-49 years old). The Susenas data then linked to official statistics. First, district's fiscal data is collected by the Ministry of Finance. This study used fiscal data from 2011 (a year prior to the Susenas survey) as district Indonesian budgeting system requires at least one year to take effect. Second, the data of the number of family planning fieldworkers $(P L K B)$ and family planning clinics in 2012 that used as the measurement of administrative decentralization are directly obtained through the official website of $B K K B N$. Official statistics data from Ministry of Home Affairs is used to obtain the data of districts that had already implemented direct elections (Pemilihan Kepala Daerah Langsung), which are used as indicators in political decentralization.

Second, in order to elaborate reasons why decentralization works and does not work, a case study is used. The case study in this study is conducted in Empat Lawang Regency, South Sumatera Province. This regency is a new district in the area, decentralized from Lahat Regency in 2007. Interviews with the Head of Family Planning Board and family planning fieldworkers were conducted in order to gain more explanation on how decentralization affect family planning policy in the area.

\section{RESULTS}

The results of this study focus on explaining why decentralization reform in the country failed to control fertility rate and to improve family welfare and seeks what strategies to enhance sound demography and welfare policy under decentralization reform.

For the first part, the estimation from Susenas 2012 revealed that none of decentralization variables were significant with fertility. Table 1 presents the regression result of one level logit and multilevel logit analyses, and shows that the standard error for the one level logit coefficient is lower than the multilevel regression coefficient. However, the estimation of one level logit is less robust than the multilevel one, because it ignores the nested structure of the data. All of decentralization variables are not significant $(p>0.05)$ means that decentralization have no association with women fertility with exception of total number of family planning clinics in district. The result shows that fertility is higher in those districts with more clinics available $(0.004, \mathrm{p}<0.05)$. 
TABLE 1 RESUlt OF LOGIT AND MULTILEVEL LOGIT REGRESSION

\begin{tabular}{|c|c|c|c|c|c|c|c|c|}
\hline \multirow[b]{3}{*}{$\begin{array}{l}\text { Log of Special Allocation Fund on } \\
\text { Family Planning }\end{array}$} & \multicolumn{4}{|c|}{ Logit } & \multicolumn{4}{|c|}{ Multilevel Logit } \\
\hline & \multirow{2}{*}{$\begin{array}{c}\text { Coef } \\
0.00^{*}\end{array}$} & \multirow{2}{*}{$\begin{array}{c}\boldsymbol{S E} \\
0.00\end{array}$} & \multicolumn{2}{|c|}{ CI 95\% } & \multirow{2}{*}{$\begin{array}{c}\text { Coef } \\
-0.00\end{array}$} & \multirow{2}{*}{ 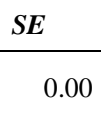 } & \multicolumn{2}{|c|}{ CI 95\% } \\
\hline & & & 0.00 & 0.00 & & & -0.01 & 0.00 \\
\hline Log of Family Planning Expenditures & $0.02 *$ & 0.00 & 0.00 & 0.03 & 0.03 & 0.03 & -0.02 & 0.09 \\
\hline$P L K B$ & $-0.00^{*}$ & 0.00 & -0.00 & -0.00 & -0.00 & 0.00 & -0.00 & 0.00 \\
\hline Family Planning Clinics & $0.00 *$ & 0.00 & 0.00 & 0.00 & $0.00 *$ & 0.00 & 0.00 & 0.00 \\
\hline Age of Local Election & 0.00 & 0.00 & -0.26 & -0.21 & -0.00 & 0.01 & -0.03 & 0.02 \\
\hline Variance between district & & & & & 0.11 & & 0.10 & \\
\hline
\end{tabular}

Note: all models were controlled by individual and household socio economic characteristics Source: Susenas 2012 and official statistics, ${ }^{*} p<0.05$

The second part is the result of a case study in Empat Lawang Regency. There are many issues faced by Family Planning Board of Empat Lawang as the consequences of decentralization reform. From the interview with the Head of Family Planning Board of Empat Lawang, it can be concluded that the issues are related with the three aspects of decentralization. Fiscally, family planning programs in Empat Lawang Regency had been carried out with very limited budget, granted accordingly to the Regional Budget. To compensate that, infrastructure projects that usually spend substantial amount of budget are funded by special allocation funds (DAK). Administratively, decentralization affects the allocations of human resources. The change of $P L K B$ status as a local government civil servant apparently leads to significant decrease in their number, due to many factors. Politically, decentralization affects policy and decision making. The head of local government, the Regent of Empat Lawang hold most of the control regarding family planning programs. Therefore, the accomplishment and the pattern of how programs can be carried out are greatly depending on his will.

As the result of decentralization policy, most of program in district level are insufficiently supported by the local budget, especially those which under-prioritized like family planning. In Empat Lawang Regency, Family Planning Board depends greatly on Special Allocation Funds to fund the infrastructures program such as the construction of family planning counseling hall, procurement of information car unit, service car unit,
$P L K B$ motorbike and many others that are crucial to carry out a sufficient service, particularly to reach out the clients that live in remote areas. Another issue is the fact that communityoriented programs in Empat Lawang are greatly depend on the amount of General Allocation Fund granted to the Family Planning Board of Empat Lawang. The larger the funds granted to Family Planning Board of Empat Lawang, the larger the portion given to the community-oriented programs, while the portion of routine expenditures (for personnel and goods \& service expenditures) are remain the same. Therefore, in the years in which Family Planning Board had insufficient funds from the regional budget, only several community-oriented programs can be conducted, that result in insufficient service.

Among the most important factors to carry out the family planning programs in Empat Lawang Regency are PLKB and family planning services facilities. PLKBs are known as the "tip of the spear" in family planning. Therefore, the quantity and the quality of $P L K B$ are very important. Table 2 shows that Empat Lawang has enough PLKB with PLKB/Villages ratio 1:2. However, almost all of PLKBs in Empat Lawang are not civil servants with inadequate skills and responsibilities. Table 2 also shows very limited family planning facilities, with no increasing number from year to year. These two indicators illustrate that the basic service performance of family planning programs in Empat Lawang regency is still weak and insufficient. 
Table 2 Basic Service Performance of FAmily Planning Programs in EMPat LaWANG RegenCy

\begin{tabular}{llccccc}
\hline \multicolumn{1}{c}{ No } & \multicolumn{1}{c}{ Performance Indicators } & $\mathbf{2 0 1 0}$ & $\mathbf{2 0 1 1}$ & $\mathbf{2 0 1 2}$ & $\mathbf{2 0 1 3}$ & $\mathbf{2 0 1 4}$ \\
\hline 1. & $P L K B$ & & & & & \\
1.1 & Total $P L K B$ & 60 & 60 & 65 & 87 & 99 \\
1.2 & Total Villages & 156 & 156 & 156 & 156 & 156 \\
1.3 & $P L K B /$ Villages ratio & $1: 3$ & $1: 3$ & $1: 3$ & $1: 2$ & $1: 2$ \\
1.4 & $P L K B$ with Basic Training Certificate & - & - & - & 7 & - \\
1.5 & $P L K B$ with University education & 11 & 13 & 12 & 13 & 25 \\
1.6 & $P L K B$ with senior high school education & 49 & 47 & 53 & 74 & 74 \\
1.7 & Total of Civil servant $P L K B$ & 1 & - & - & 2 & - \\
1.8 & Total of non-civil servant $P L K B$ & 59 & 60 & 65 & 85 & 99 \\
2. & Family Planning services facilities & & & & & 1 \\
2.1 & Hospital & 0 & 0 & 1 & 1 & 1 \\
2.2 & Community Health Center (district) & 8 & 8 & 9 & 9 & 9 \\
2.3 & Community Health Center (village) & 12 & 12 & 12 & 12 & 12 \\
2.4 & Community Health Post & & & & & 80 \\
& Family Planning clinics & 80 & 80 & 80 & 80 & 8 \\
\hline
\end{tabular}

Furthermore, as shown by Table 3, although the number of village remains the same, the number of women of reproductive age (WRA) continues to grow every year. For example, in Tebing Tinggi sub-district, 8-16 PLKBs have to take care of 7,431-18,393 WRA.

TABle 3 RATio PLKB TO VILLAGES AND WOMEN OF REPRODUCTIVE AGE (WRA) IN EMPAT LAWANG REGENCY

\begin{tabular}{|c|c|c|c|c|c|c|c|c|c|c|c|c|}
\hline \multirow{2}{*}{ No } & \multirow{2}{*}{ Sub-district } & \multirow{2}{*}{$\begin{array}{c}\text { No of } \\
\text { Villages }\end{array}$} & \multicolumn{2}{|c|}{2010} & \multicolumn{2}{|c|}{2011} & \multicolumn{2}{|c|}{2012} & \multicolumn{2}{|c|}{2013} & \multicolumn{2}{|c|}{2014} \\
\hline & & & WRA & $P L K B$ & $W R A$ & $P L K B$ & WRA & $P L K B$ & WRA & $P L K B$ & WRA & PLKB \\
\hline 1 & $\begin{array}{l}\text { Tebing } \\
\text { Tinggi }\end{array}$ & 26 & 7,431 & 16 & 15,958 & 14 & 18,393 & 14 & 14,062 & 8 & 15,582 & 10 \\
\hline 2 & $\begin{array}{l}\text { Talang } \\
\text { Padang }\end{array}$ & 13 & 895 & 6 & 3,263 & 6 & 2626 & 6 & 5,225 & 8 & 3,010 & 8 \\
\hline 3 & Pendopo & 19 & 11,551 & 11 & 15,925 & 11 & 15,484 & 11 & 10,555 & 14 & 11,537 & 17 \\
\hline 4 & $\begin{array}{l}\text { Pendopo } \\
\text { Barat* }\end{array}$ & 10 & & & & & & & 4,007 & 11 & 4,303 & 9 \\
\hline 5 & Ulu Musi & 14 & 8,381 & 8 & 8,961 & 8 & 9,699 & 6 & 5,368 & 6 & 5,591 & 5 \\
\hline 6 & $\begin{array}{l}\text { Sikap } \\
\text { Dalam* }\end{array}$ & 11 & & & & & & 3 & 4,655 & 3 & 5,386 & 5 \\
\hline 7 & $\begin{array}{l}\text { Pasemah Air } \\
\text { Keruh }\end{array}$ & 15 & 5,146 & 6 & 5,666 & 7 & 5,699 & 7 & 5,848 & 7 & 5,598 & 8 \\
\hline 8 & Muara Pinang & 22 & 7,211 & 7 & 7,668 & 8 & 7,678 & 12 & 7,971 & 14 & 9,064 & 18 \\
\hline 9 & $\begin{array}{l}\text { Lintang } \\
\text { Kanan }\end{array}$ & 16 & 6,451 & 6 & 8,634 & 6 & 7,533 & 6 & 8,323 & 9 & 8,516 & 12 \\
\hline \multirow[t]{2}{*}{10} & Saling* & 10 & & & & & & & 4,212 & 7 & 4,554 & 7 \\
\hline & Total & 156 & 47066 & 60 & 66075 & 60 & 67112 & 65 & 70226 & 87 & 73141 & 99 \\
\hline
\end{tabular}

Political autonomy measures the discretionary power in political decision making awarded to each district [5]. For Empat Lawang Regency, as the result of local election, the Regent is the person who had the most power in policy and decision making in all aspects of administration including family planning. This is the reason why the accomplishment of family planning programs is not only depended on Family
Planning Board as the local government agency responsible for the matter, but also greatly depend on the Regent and his will. The accomplishment of family planning programs in Empat Lawang is not only depends on the performance of Family Planning Board, but also greatly depend on the support of Regent himself. Even when the performance of Family Planning Board of Empat Lawang is at its best, without the 
support of Regent, some programs cannot be conducted thus effect the overall accomplishment. There is also policy of compulsion to coordinate every Central government's program and policy with the Regent. Every program and policy that came from Central Government has to be coordinated first with the Regent, indicates that Family Planning Board Empat Lawang cannot adopt said program and policy immediately. Central government's program and policy may or may not be able to conduct in the regency is greatly depend on the decision of the Regent or his Vice. Another issue is the fact that Family Planning Board of Empat Lawang is autonomous; the relationship with Central $B K K B N$ and Province $B K K B N$ is limited to coordination only. Without commando relationship as carried out in centralization era, Family Planning Board of Empat Lawang has to formulate its own programs, adjust its policies and programs with the local government's regulation and more importantly defend its own programs to gain sufficient funds.

\section{DISCUSSION}

This study examines why decentralization reform in the country failed to control fertility rate and to improve family welfare and seeks what strategies to enhance sound demography and welfare policy under decentralization reform. The main results show that none of those three types of decentralization have significant association toward fertility, means that decentralization have no association with decreasing or increasing fertility rate.

This result confirms the findings of previous studies argued that decentralization process in Indonesia, which commonly known as "regional autonomy" has a major flaw in design and preparation [6][7]. The rush preparation and poorly designed laws of decentralization did not take into account the inequality of region's capacity, so they cannot be imposed effectively and conversely produce perverse effects, especially for poor and less developed regions [8]. Furthermore, they have no clear general framework on how to carry out the goals of the reform [9]. Various problems arise during the short implementation period such as unclear division of authorities among the tiers of government causing a struggle for authorities among them, inefficient resource allocation caused by the low capacity and demoralization of civil servants within the regional governments, widening disparity among regions, and stronger primordial ties based on ethnic and religion [10] [11].

The findings of qualitative data also confirm the result of quantitative one. Empat Lawang regency is facing similar typical problem in implementing decentralization. Fiscally, the intergovernmental transfer and grants consist of General Allocation Fund (DAU) and Special Allocation Fund (DAK) remains to be the most important revenue resource for the family planning programs in Empat Lawang regency. Moreover, the absence of local revenue in funding the programs and inefficiency in budget allocation means that Empat Lawang' s government is lacking in fiscal capacity, merely depend on the transfer from central government. Administratively, the human resources in Empat Lawang regency are very limited both in quantity and quality. To compensate the highly limited number of civil-servant PLKB, Family Planning Board of Empat Lawang regency recruited some non-civil servant $P L K B$, with inadequate skills and knowledge. This matter confirms the finding of Seymour and Turner (2002) [10] who stated that "the capability of human resources, especially those at the districts and municipalities are not ready yet", revealing that local governments suffer from a shortage of qualified personnel and managers to shoulder the new responsibilities brought by decentralization [12] [13] [14]. Politically, the elected Regent holds most power in the region. The accomplishment of family planning programs in Empat Lawang is not only depend on Family Planning Board as the local agency responsible to the matter, but also greatly depend on the Regent's will. Moreover, there is no citizen's control over the performance of the government as there is no 'recall' mechanism provided for the incumbent government if they perform badly. These entire problems combined resulting in weak performance on family planning programs; this is why decentralization that supposedly brings a better condition to the community is not associated with family planning goals such as decreasing fertility.

From the results, several implications can be made into strategy recommendations to enhance sound demography and welfare policy under decentralization reform. First and foremost, the central government needs to take a lead in reformulation of family planning management in district level. Second, to assure that the family planning program has expanding resources and qualified personnel to provide the needs of growing population of women of childbearing age, major recruitment of $P L K B$ is needed, particularly for village level. The management shift policy of $P L K B$ from local to central government that has been implemented gradually from 2016 until recently is one of the efforts from the government to revitalize the family planning service in decentralized era. Third, initiation of local political leadership and family planning health services program managers in the districts. To develop the political will of the local leader are both the most difficult and crucial part in enhancing sound demography and welfare policy under decentralization. This effort can be achieved through consistent courses that developed to reintroduce the significance of family planning to overall development goals, including best method for financial management and techniques to ensure quality of services.

This study was made with a number of limitations that should be taking into consideration. Firstly, because this study only uses one-year data, it cannot illustrate the trends and a meaningful relationship between dependent and independent variables. The future research could add two or more years to make a trend and find more meaningful relationship between those variables. Secondly, due to its cross-sectional design, we have to be careful on how to interpret the associations. The estimated coefficient should be viewed as a measure of association rather than of causation. The causal effect of decentralization and fertility is something which future research should investigate further. Thirdly, this study used a case study conducted in new decentralized district in particular area of Indonesia, therefore the result from the case study cannot be generalized to other area in Indonesia. 


\section{CONCLUSION}

This study concludes that decentralization reform in Indonesia is ineffective for controlling fertility rate and improve family welfare. Some strategies can be proposed to enhance sound demography and welfare policy under decentralized reform in the country. First, the central government needs to take a lead in reformulation of family planning management in district level; second, major recruitment of PLKB particularly for village level; third, consistent courses of re-introducing the significance of family planning to overall development goals to develop the political will of local leader in district level; and fourth, this study highlights that family planning policy could not be pursued successfully without promoting socio-economic conditions such as female literacy, the general quality of life, reproductive health and family welfare.

\section{REFERENCES}

[1] Hull, T. H., \& Mosley, H. (2009). Revitalization of family planning in Indonesia.

[2] BPS, BKKBN, \& Kementerian Kesehatan RI. (2012). Survei Demografi dan Kesehata Indonesia 2012.

[3] Pasay, N.H.A., \& Wongkaren, T.S. (2001). Population policies and program in Indonesia.

[4] Jones, G., \& Adioetomo, SM. (2014). Population, Family Planning and Reproductive Health.

[5] Schneider, A. (2003). Decentralization: Conceptualization and measurement. Studies in comparative international development, 38(3), 32.

[6] Sujarwoto. (2012). Political decentralization and local public service performance in Indonesia. Journal of Public Administration and Governance, 2(3), pp. 55-84.

[7] Sujarwoto \& Tampubolon, G. (2015). Decentralisation and citizen happiness: A multilevel analysis of self-rated happiness in Indonesia. Journal of Happiness Studies, 16 (2), pp. 455-475

[8] Robalino, M. G., Picazo, O. F., \& Voetberg, A. (2001). Does fiscal decentralization improve health outcomes? Evidence for cross country analysis. World Bank Country Economics Department Series 2565. The World Bank.

[9] Alm, J.A., \& Bahl, R. (2001).Can Indonesia decentralise successfully? Plans, problems, and prospects.

[10] Seymour, R., \& Turner, S. (2002). Otonomi daerah: Indonesia's decentralisation experiment. New Zealand Journal of Asian Studies, 4 , 33-51.

[11] Sujarwoto \& Tampubolon, G. (2016). Spatial inequality and internet divide in Indonesia. Telecommunication Policy, 40

[12] Asfaw, A. \& Frohberg, K. \& James, K. S. \& Jutting, J. (2007). Fiscal decentralization and infant mortality: Empirical evidence from rural India. The Journal of Developing Areas 41(1), 17-35.

[13] Litvack, J., \& Seddon, J. (1999). Decentralization briefing notes. World Bank Institute, Washington, DC

[14] Saunders, M. \& Sharma, S. (2008). Mobilizing political support and resources for family planning in a decentralized setting: Guidelines for Latin American and Caribbean countries. Washington, DC: Health Policy Initiative, Task Order I, Futures Group International.

\section{BIOGRAPHY}

\section{TRIA ABRIANTY}

Master's degree candidate of Brawijaya University, Faculty of Public Administration. I am a local government official work in Family Planning Board of Empat Lawang Regency, South Sumatra Province (since 2010).

\section{SUJARWOTO SUJARWOTO}

Lecturer at Faculty of Public Administration, Brawijaya University (from 2003) and currently responsible as the Director of Centre of Public Service Innovation and Public Service Reform at Faculty of Administrative Science Brawijaya University. Graduated with MA and PhD from University of Manchester UK, I am a public policy and social change specialist with focus on decentralization, population health and well-being. 